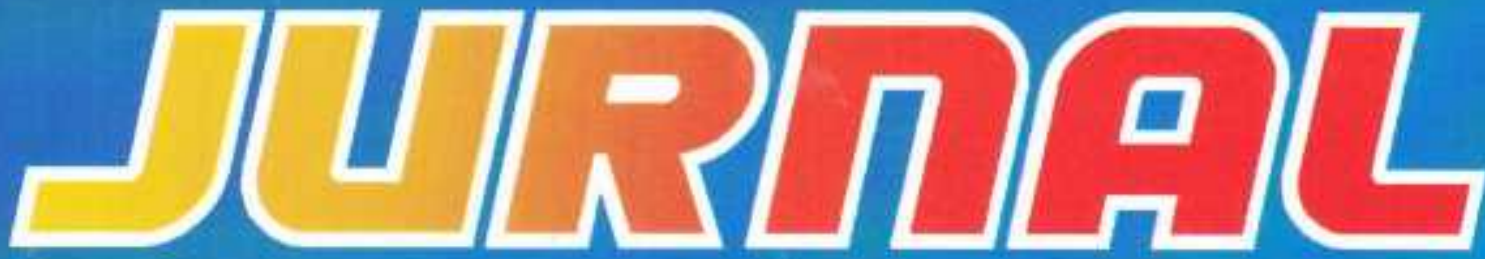

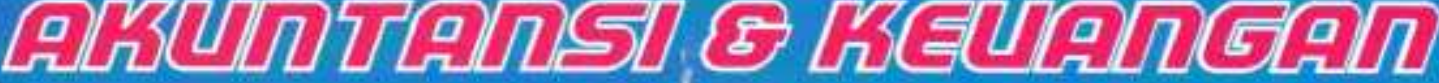

Volume 6, No. 1, Maret 2015

ISSN: $2087-2054$

Pengaruh Peran Acoount Representative Terhadap Tingkat Kepatuhan Wajib Pajak (Studi kasus pada KPP Pratama di Kota Bandar Lampung)

\section{Angrita Denziana \& Handi Sutanto}

Pengaruh Biaya Iklan Dan Biaya Penjualan Personal Terhadap Nilai Penjualan Pada PT Telekomunikasi Indonesia, Tbk.

\section{Chairul Anwar \& Rinna}

Relationship Executives Rewards With Financial Performance On Corporate Banking In Indonesia

\section{Haninun \& Putri Cagora Nisa}

Analisis Penerapan Metode Pengakuan Pendapatan Terhadap Laba Perusahaan Pada Pt. Coca Cola Distribusi Indonesia (Cabang Tanjung Karang)

\section{Herry Goenawan Soedarsa \& Surya Pandelima}

Pengaruh Tingkat Suku Bunga Simpanan Terhadap Jumlah Deposito Pada Pt. Bank Rakyat Indonesia (Persero) Tbk. Cabang Liwa

\section{Indrayenti \& Susanti}

Pengaruh Motivasi Terhadap Minat Mahasiswa Akuntansi Untuk Mengikuti Pendidikan Profesi Akuntansi (PPAK) Di Provinsi Lampung

\section{Rosmiaty Tarmizi \& Julia Restuti}

Pengaruh Kinerja Hutang Terhadap Nilai Perusahaan Pada Perusahaan Pertambangan Batubara Yang Terdaftar Di Bei Periode 2010-2013

\section{Khairudin \& Rico Tanto}

Pengaruh Profitabilitas, Ukuran Perusahaan, Debt To Equity Terhadap Ketepatan Waktu Penyampaian Laporan Keuangan (Studi Pada Perusahaan Asuransi Yang Terdaftar Di BEI)

\section{Riswan \& Tri Lestari Saputri}

Pengaruh Manajemen Laba Terhadap Kinerja Keuangan Pada Perusahaam Manufaktur Tahun 2011-2012

\section{Aminah \& Lidya Natasia Gunakan}




\section{Dewan Pembina}

Dr. Ir. M. Yusuf S. Barusman, M.B.A

Dr. Andala Rama Putra Barusman, S.E., M.A.Ec.

\section{Penanggung Jawab}

Dra. Rosmiaty Tarmizi, M.M.Akt. C.A

\section{Pimpinan Redaksi}

Dr. Angrita Denziana, S.E., M.M, Ak. C.A

\section{Sekretaris Redaksi}

Aminah, S.E., M.S.Ak

Khairudin, S.E., M.S.Ak

\section{Penyuting Ahli}

Prof. Dr. Jogiyanto Hartono, M.B.A. ( Universitas Gadjah Mada)

Tina Miniawati, S.E., M.B.A. (Universitas Trisakti)

Dr. Khomsiyah, S.E., M.M. (Universitas Trisakti)

Dr. Lindrianasari, S.E., M.Si.Akt. (Universitas Lampung)

Sujoko Efferin, Mcom (Hons), MA(Econ), Ph.D. (Universitas Surabaya)

\section{Penerbit}

Universitas Bandar Lampung

Fakultas Ekonomi dan Bisnis Program Studi Akuntansi

SENARAI-Jurnal Akuntansi \& Keuangan Terbit 2 kali setahun pada bulan Maret \&

September

Artikel yang dimuat berupa hasil riset Empiris dan telaah teoritis konsepsual yang kritis dalam kajian bidang akuntansi, auditing, perpajakan, dan keuangan.

\section{Alamat Redaksi}

Gedung G- Program Studi Akuntansi Fakultas Ekonomi dan Bisnis Universitas Bandar Lampung

Kampus A Jalan Z.A Pagar Alam No. 26 Labuan Ratu Bandar Lampung 35142

Telp: (0721) 701979, Fax: (0721) 701467, Email: Prodi.akuntansi@ubl.ac.id 


\section{JURNAL \\ AKUNTANSI \& KEUANGAN}

Volume 6, No. 1, Maret 2015

ISSN: 2087-2054

Pengaruh Peran Acoount Representative Terhadap Tingkat Kepatuhan Wajib Pajak

(Studi Kasus pada KPP Pratama di Kota Bandar Lampung)

Angrita Denziana \& Handi Sutanto

Pengaruh Biaya Iklan dan Biaya Penjualan Personal Terhadap Nilai Penjualan Pada PT

Telekomunikasi Indonesia, Tbk.

\section{Chairul Anwar \& Rinna}

Relationship Executives Rewards With Financial Performance On Corporate Banking In Indonesia

\section{Haninun \& Putri Cagora Nisa}

Analisis Penerapan Metode Pengakuan Pendapatan Terhadap Laba Perusahaan Pada PT. Coca Cola Distribusi Indonesia (Cabang Tanjung Karang)

Herry Goenawan Soedarsa \& Surya Pandelima

Pengaruh Tingkat Suku Bunga Simpanan Terhadap Jumlah Deposito Pada PT. Bank Rakyat Indonesia (Persero) Tbk. Cabang Liwa

Indrayenti \& Susanti

Pengaruh Motivasi Terhadap Minat Mahasiswa Akuntansi Untuk Mengikuti Pendidikan Profesi Akuntansi (PPAK) Di Provinsi Lampung

\section{Rosmiaty Tarmizi \& Julia Restuti}

Pengaruh Kinerja Hutang Terhadap Nilai Perusahaan Pada Perusahaan Pertambangan Batubara Yang Terdaftar Di BEI Periode 2010-2013

\section{Khairudin \& Rico Tanto}

Pengaruh Profitabilitas, Ukuran Perusahaan, Debt To Equity Terhadap Ketepatan Waktu Penyampaian Laporan Keuangan (Studi Pada Perusahaan Asuransi Yang Terdaftar Di BEI) Riswan \& Tri Lestari Saputri

Pengaruh Manajemen Laba Terhadap Kinerja Keuangan Pada Perusahaam Manufaktur Tahun 2011-2012

\section{Aminah \& Lidya Natasia Gunakan}




\section{JURNAL \\ AKUNTANSI \& KEUANGAN}

Volume 6, No. 1, Maret 2015

ISSN: 2087-2054

Daftar Isi

Halaman

$1-22$

Pengaruh Peran Acoount Representative Terhadap Tingkat Kepatuhan

Wajib Pajak (Studi kasus pada KPP Pratama di Kota Bandar Lampung)

Angrita Denziana \& Handi Sutanto

Pengaruh Biaya Iklan Dan Biaya Penjualan Personal Terhadap Nilai

Penjualan Pada PT Telekomunikasi Indonesia, Tbk.

Chairul Anwar \& Rinna

Relationship Executives Rewards With Financial Performance On

Corporate Banking In Indonesia

Haninun \& Putri Cagora Nisa

Analisis Penerapan Metode Pengakuan Pendapatan Terhadap Laba

Perusahaan Pada PT. Coca Cola Distribusi Indonesia (Cabang Tanjung

Karang)

Herry Goenawan Soedarsa \& Surya Pandelima

Pengaruh Tingkat Suku Bunga Simpanan Terhadap Jumlah Deposito Pada

PT. Bank Rakyat Indonesia (Persero) Tbk. Cabang Liwa

Indrayenti \& Susanti

Pengaruh Motivasi Terhadap Minat Mahasiswa Akuntansi Untuk

Mengikuti Pendidikan Profesi Akuntansi (PPAK) Di Provinsi Lampung

Rosmiaty Tarmizi \& Julia Restuti

Pengaruh Kinerja Hutang Terhadap Nilai Perusahaan Pada Perusahaan

Pertambangan Batubara Yang Terdaftar Di BEI Periode 2010-2013

\section{Khairudin \& Rico Tanto}

Pengaruh Profitabilitas, Ukuran Perusahaan, Debt To Equity Terhadap

Ketepatan Waktu Penyampaian Laporan Keuangan (Studi Pada Perusahaan Asuransi Yang Terdaftar Di BEI)

Riswan \& Tri Lestari Saputri

Pengaruh Manajemen Laba Terhadap Kinerja Keuangan Pada Perusahaam Manufaktur Tahun 2011-2012

Aminah \& Lidya Natasia Gunakan 


\section{JURNAL AKUNTANSI \& KEUANGAN}

Volume 6, No. 1, Maret 2015

ISSN: $2087-2054$

\section{Informasi Kebijakan dan Selingkung Berkala}

\section{Kebijakan editorial}

JURNAL Akuntansi \& Keuangan adalah sebuah berkala yang dipublikasikan oleh Universitas Bandar Lampung, yang bertujuan untuk menjadi wadah kreatifitas para akademisi, profesional, peneliti, dan mahasiswa di bidang Akuntansi dan Keuangan termasuk juga bidang Auditing, Sistem Informasi Akuntansi, Tata kelola Perusahaan, Perpajakan, Akuntansi Internasional, Akuntansi Managemen, Akuntansi Keperilakuaan, Pasar Modal dan lain sebagainya. Topik yang semakin meluas di bidang kajian riset Akuntansi diakomodir publikasinya di dalam berkala ini.

Paper yang akan dipublikasikan di dalam berkala JURNAL Akuntansi \& Keuangan harus ditulis di dalam bahasa Indonesia yang baik dan sesuai dengan EYD. Semua instrumen yang digunakan untuk memperoleh data penelitian harus dimasukkan di dalam lampiran paper penelitian, paling tidak, penulis bersedia memberikan klarifikasi atas instrumen yang digunakan saat ada permintaan dari peneliti lainnya.

\section{Sekretariat Editor Berkala}

Gedung F - Fakultas Ekonomi Universitas Bandar Lampung

Fakultas Ekonomi Program Studi Akuntansi

Kampus A Jalan Z.A. Pagar Alam No. 26 Labuhan Ratu Bandar Lampung 35142

$$
\text { Telp.: (0721) 701979, Fax.: (0721) 701467, Email: }
$$

\section{Petunjuk penulisan}

Artikel yang dikirim ke JURNAL Akuntansi \& Keuangan harus mengikuti petunjuk seperti berikut:

1. Naskah merupakan naskah asli yang belum pernah diterbitkan atau sedang dilakukan penilaian pada berkala lain. Naskah ditulis dalam bahasa Indonesia dengan jarak 1 spasi, sepanjang 20-30 halaman kertas A4 dengan tipe huruf Times New Roman.. Naskah dikirim atau diserahkan ke sekretariat JURNAL Akuntansi \& Keuangan rangkap satu disertai disket berikut dengan biodata penulis dan alamat lengkap (kantor dan rumah) pada lembaran yang terpisah dari halaman pertama artikel.

2. Judul naskah dapat ditulis dengan menggambarkan isi pokok tulisan, dan atau ditulis secara ringkas, jelas, dan menarik. 
3. Nama Penulis disertai catatan kaki tentang profesi dan lembaga tempat penulis bekerja dalam naskah yang telah diterima untuk diterbutkan.

4. Abstrak ketik satu spasi, tidak lebih dari 250 kata dalam bahasa Inggris. Abstrak memuat tujuan penelitian, isu, permasalahan, sampel dan metode penelitian, serta hasil dan simpulan (jika memungkinan).

5. Pendahuluan beriksikan uraian tentang latar belakang masalah, ruang lingkup penelitian, dan telaah pustaka yang terkait dengan permasalahan yang dikaji, serta rumusan hipotesis (jika ada). Uraian pendahuluan maksimum $10 \%$ total halaman.

6. Untuk penelitian kuantitatif,

a. Telaah Literatur dan Pengembangan Hipotesis memuat paling tidak satu buah teori yang menjadi dasar pemikiran penelitian. Hipotesis dikembangkan menggunakan asumsi dasar teori dan hasil penelitian sebelumnya. Telah literatur maksimum $40 \%$ total halaman.

b. Metodologi Penelitian meliputi uraian yang rinci tentang bahan yang digunakan, metoda yang dipilih, teknik, dan cakupan penelitian. Uraian bahan dan metoda maksimum $20 \%$ total halaman.

7. Untuk penelitian kualitatif menyesuaikan dengan metodologi kualitatif.

8. Hasil dan Pembahasan merupakan uraian obyektif dari-hasil penelitian dan pembahasan dilakukan untuk memperkaya makna hasil penelitian. Uraian hasil dan pembahasan minimum $25 \%$ total halaman.

9. Simpulan yang merupakan rumusan dari hasil-hasil penelitian. Harus ada sajian dalam satu kalimat inti yang menjadi simpulan utama. Simpulan maksimum 10\% dari keseluruhan lembar artikel.

10. Referensi (Daftar Pustaka) ditulis berurutan berdasarkan alphabetical, disusun menggunakan suku kata terakhir dari nama penulisnya, atau institusi jika dikeluarkan oleh organisasi.

a. Buku: nama penulis, tahun penerbitan, judul lengkap buku, penyunting (jika ada), nama penerbit, dan kota penerbitan.

b. Artikel dalam buku: nama penulis, tahun penerbitan, judul artikel/tulisan, judul buku, nama penyunting, kota penerbitan, nama penerbit, dan halaman.

c. Terbitan berkala: nama penulis, tahun penerbitan, judul tulisan, judul terbitan (bila disingkat, sebaiknya menggunakan singkatan yang baku), volume, nomor, dan halaman.

d. Artikel dalam internet: nama penulis, judul, dan situsnya.

e. Tabel diberi nomor dan judul dilengkapi dengan sumber data yang ditulis dibawah badan tabel, diikuti tempat dan waktu pengambilan data.

f. Ilustrasi dapat berupa gambar, grafik, diagram, peta, dan foto diberi nomor dan judul.

11. Setiap referensi yang digunakan di dalam naskah artikel menggunakan petunjuk yang dirujuk pada The Indonesian Journal of Accounting Research, sebagai berikut:

A. Kutipan dalam tubuh naskah paper harus disesuaikan dengan contoh berikut:

I. Satu sumber kutipan dengan satu penulis (Brownell, 1981).

II. Satu sumber kutipan dengan dua penulis (Frucot dan Shearon, 1991).

III. Satu sumber kutipan dengan lebih dari satu penulis (Hotstede et al., 1990).

IV. Dua sumber kutipan dengan penulis yang berbeda (Dunk, 1990; Mia, 1988).

V. Dua sumber kutipan dengan satu penulis (Brownell, 1981, 1983).

VI. Dua sumber kutipan dengan satu penulis diterbitkan pada tahun yang sama (Brownell, 1982a, 1982b). 
VII. Sumber kutipan dari lembaga harus dinyatakan dengan menggunakan akronim institusi (FASB, 1994)

B. Setiap artikel harus menulis referensi menggunakan panduan berikut:

I. Referensi harus tercantum dalam urutan abjad dari nama belakang penulis atau nama lembaga.

II. Referensi harus dinyatakan dengan urutan sebagai berikut: penulis (s) nama, tahun publikasi, judul kertas atau buku teks, nama jurnal atau penerbit dan nomor halaman. Contoh:

a) Amerika Akuntansi Association, Komite Konsep dan Standar Laporan Keuangan Eksternal. 1977. Pernyataan tentang Teori Akuntansi dan Teori Penerimaan. Sarasota, FL: AAA.

b) Demski, J. S., dan D. E. M. Sappington. 1989. Struktur hirarkis dan akuntansi pertanggungjawaban, Jurnal Akuntansi Penelitian 27 (Spring): 40-58.

c) Dye, R. B., dan R. Magee. 1989. Biaya Kontijensi untuk perusahaan audit. Kertas kerja, Northwestern University, Evansto, IL.

d) Indriantoro, N. 1993. Pengaruh Penganggaran Partisipatif Terhadap Prestasi Kerja dan Kepuasan Kerja dengan Locus of Control dan Dimensi Budaya sebagai Moderating Variabel. Ph.D. Disertasi. University of Kentucky, Lexington.

e) Naim, A. 1997. Analisis Penggunaan Akuntansi Biaya Produk Dalam Keputusan Harga oligopolistik. Jurnal Ekonomi Dan Bisnis Indonesia 12 (3): 43-50.

f) Porcano, T. M. 1984a. Keadilan distributif dan Kebijakan Pajak. Akuntansi Ulasan 59 (4): 619-636.

g) -------. 1984b. Pengaruh Persepsi Kebijakan Pajak Niat Investasi Perusahaan. The Journal of American Association Perpajakan 6 (Fall): 719.

h) Pyndyk, R. S. dan D. L. Rubinfield. 1987. Model ekonometrik \& Forecasts Ekonomi, 3rd ed. NY: McGraw-Hill Publishing, Inc.

12. Author(s) harus melampirkan CV, alamat email, alamat korespondensi dan pernyataan yang menyatakan pasal tersebut tidak sedang disampaikan kepada atau diterbitkan oleh jurnal lain dalam email tersebut dan /atau pos. 


\title{
PENGARUH MANAJEMEN LABA TERHADAP KINERJA KEUANGAN PADA PERUSAHAAM MANUFAKTUR TAHUN 2011-2012
}

\author{
Aminah \\ Lidya Natasia Gunakan \\ (Universitas Bandar Lampung) \\ email:amy_ubl@ymail.com \\ email: leedyanatasia@gmail.com
}

\begin{abstract}
This study aims to obtain empirical evidence about the effect of earnings management on financial performance. Earnings management is the act which is conducted by manager to maximize, minimize, or do income smoothing of company's profit. Managers can affect their company's market value by do earnings management, such as make their profit always increase every year to show their good financial performance. Indipendent variable of this study is earnings management that measured by discretionary accruals and dependent variable is financial performance that measured by return on asset and debt to equity ratio. This study use analysis of descriptive statistics, simple linier regression with $t$ test and coefficient determination by SPSS 18 program. Samples of this study are 15 manufacturing companies obtained in Indonesia Stock Exchange (BEI) from 2011-2012 period. The results of this study showed that earnings management affect return on asset positive significantly and earnings management affect debt to equity ratio negative unsignificantly.
\end{abstract}

Keywords: Dicretionary Accruals, Return on Asset and Debt to Equity Ratio.

\section{Latar Belakang}

Salah satu tujuan utama perusahaan adalah untuk memperoleh laba dari usaha yang dijalankan tersebut. Laba merupakan selisih antara pendapatan yang diterima oleh perusahaan dikurangi dengan biaya-biaya yang dikeluarkan oleh perusahaan selama periode tertentu. Laba yang dilaporkan perusahaan, digunakan sebagai signal kepada investor untuk melihat kinerja keuangan perusahaan sehingga mereka tertarik untuk menanamkan modal di perusahaan tersebut.

Manajemen laba adalah suatu tindakan yang dilakukan oleh manajer untuk memaksimumkan, meminimumkan, ataupun melakukan perataan laba perusahaan. Pihak manajemen sebagai pengelola perusahaan dapat mempengaruhi nilai pasar perusahaannya melalui manajemen laba, seperti menunjukkan laba yang terus meningkat setiap tahun yang menunjukkan keberhasilan suatu perusahaan. Hal ini dapat menarik para investor untuk menananamkan modal di perusahaan tersebut.

Kinerja perusahaan adalah suatu usaha nyata yang dilakukan perusahaan untuk menilai efisiensi dan efektivitas dari aktivitas yang dilakukan oleh perusahaan yang telah dilaksanakan selama periode waktu tertentu. Sedangkan kinerja keuangan adalah suatu usaha 
nyata yang dilakukan oleh perusahaan yang dapat digunakan untuk mengukur keberhasilan perusahaan dalam menghasilkan laba, sehingga dapat melihat prospek, potensi, serta pertumbuhan baik suatu perusahaan.

Manajemen laba dilakukan oleh manajer untuk memenuhi tanggung jawab terhadap pemilik perusahaan akan laba yang terus meningkat dan nilai pasar perusahaan yang naik pada jangka waktu tertentu, sehingga mereka dikontrak kembali untuk menjabat sebagai manajer di perusahaan tersebut di periode berikutnya. Kurangnya informasi dan pengetahuan pemilik perusahaan dan pihak eksternal perusahaan seperti investor, serta terpusatnya perhatian pemilik perusahaan dan investor terhadap laba seringkali mendorong manajer untuk memanipulasi laba. Hal ini dapat mengakibatkan munculnya potensi pelanggaran dan kejahatan yang dibuat oleh pihak manajemen perusahaan. Namun, manajemen laba tidak selalu menjadi upaya negatif yang merugikan karena tidak selamanya manajemen laba berorientasi pada memanipulasi data akuntansi, tetapi lebih condong terhadap pemilihan metode akuntansi yang dipilih oleh pihak manajemen untuk tujuan tertentu dalam batasan GAAP.

Saat ini manajemen laba telah menjadi suatu fenomena umum yang terjadi di sejumlah perusahaan baik di dalam maupun di luar negeri. Perusahaan Xerox Corp, perusahaan WorldCom sebagai salah satu perusahaan telekomunikasi terbesar di Amerika juga melakukan manipulasi laporan keuangan dengan manipulasi sebesar US\$3,8 miliar. Selain kasus manajemen laba di Amerika Serikat, beberapa kasus serupa terjadi di Indonesia antara lain PT. Kimia Farma Tbk dan PT. Lippo TBk yang melakukan manajemen laba dalam hal pelaporan keuangan.

\section{Tinjauan Pustaka}

\subsection{Teori Signaling}

Informasi laba yang dilaporkan manajemen merupakan sinyal mengenai laba di masa yang akan datang, oleh karena itu pengguna laporan keuangan dapat membuat prediksi atas laba perusahaan di masa yang akan datang (Assih, 2000). Informasi laba menjadi indikator dalam menganalisis nilai suatu perusahaan bagi pelaku di pasar modal. Jika investor bertransaksi dalam sebuah pasar yang efisien, maka mereka dapat mendasarkan pada hargaharga yang merefleksikan berbagai rangkaian informasi, termasuk informasi laporan keuangan, dan mereka tidak harus memproses semua informasi secara langsung (Beaver, 2002). Kualitas keputusan investor dipengaruhi oleh kualitas informasi yang diungkapkan 
perusahaan dalam laporan keuangan (Maria, 2006). Kualitas informasi yang baik bertujuan agar tidak terjadi perbedaan informasi yang diterima oleh pihak pemilik perusahaan ataupun pihak eksternal perusahaan dari pihak pengelola perusahaan. Teori signalling bertujuan membantu pihak pemilik, pengelola, dan investor mengurangi perbedaan informasi tentang kondisi perusahaan yang mempengaruhi kualitas laporan keuangan.

\section{Teori Akuntansi Positif}

Teori Akuntansi Positif mengusulkan tiga hipotesis yang mendorong perusahaan untuk melakukan manajemen laba, yaitu (Watts, 1986):

a. Bonus Plan Hypothesis

Manajemen akan memilih metode akuntansi yang memaksimalkan utilitasnya yaitu bonus yang tinggi. Manajer perusahaan yang memberikan bonus besar berdasarkan laba lebih banyak menggunakan metode akuntansi yang meningkatkan laba yang dilaporkan.

b. Debt Covenant Hypothesis

Manajer perusahaan yang melakukan pelanggaran perjanjian kredit cenderung memilih metode akuntansi yang memiliki dampak meningkatkan laba (Rahmawati, 2006). Hal ini untuk menjaga reputasi mereka dalam pandangan pihak eksternal.

c. Political Cost Hypothesis

Semakin besar perusahaan, semakin besar pula kemungkinan perusahaan tersebut memilih metode akuntansi yang menurunkan laba. Hal tersebut dikarenakan dengan laba yang tinggi pemerintah akan segera mengambil tindakan, misalnya: menaikkan pajak pendapatan perusahaan.

\subsection{Penelitian Terdahulu dan Hipotesis}

Beberapa penelitian terdahulu yang telah dilakukan manajemen laba diantaranya dilakukan Elok (2012) Manajemen Laba berpengaruh negatif terhadap kinerja keuangan perusahaan. Artinya pengaruh yang diakibatkan dari praktik manajemen laba memberikan dampak menurunnya kinerja keuangan perusahaan. Penelitian Dewi et al (2009) juga telah mencoba untuk menguji pengaruh signifikan antara manajemen laba terhadap kinerja keuangan perusahaan yang diproksikan melalui ROA. Berdasarkan hasil penelitian, kesimpulan dari hasil penelitian menunjukkan bahwa manajemen laba akrual berpengaruh terhadap kinerja keuangan perusahaan. 
Chung et al (2005) berusaha menemukan adanya pengaruh manajemen laba terhadap kinerja perusahaan. Dalam studinya, ditemukan motif untuk melakukan manajemen laba dengan discretionary accruals untuk meningkatkan laba perusahaan yang berpengaruh positif terhadp profitabilitas perusahaan.

Penelitian ini mengacu pada penelitian Dewi et al (2009) yang dahulu meneliti tentang pengaruh manajemen laba akrual terhadap kinerja keuangan perusahaan pada sektor manufaktur pada periode tahun 2004-2007. Penelitian ini bertujuan untuk meneliti kembali apakah terdapat pengaruh manajemen laba terhadap kinerja keuangan perusahaan. Perbedaan penelitian ini dengan penelitian terdahulu yang dilakukan oleh Dewi et al (2009) terletak pada periode tahun penelitian yang dilakukan selama tahun 2010-2011, dan indikator penelitan yang sebelumnya hanya rasio profitabilitas dalam mengukur kinerja keuangan saja ditambah menjadi rasio profitabilitas dan solvabilitas.

Berdasarkan uraian tersebut, maka dapat dirumuskan hipotesis sebagai berikut:

H1 : Manajemen laba berpengaruh terhadap Return On Asset Perusahaan.

H2 : Manajemen laba berpengaruh terhadap Debt to Equity Ratio

Perusahaan.

\section{Metodologi Penelitian}

\subsection{Pemilihan Sampel}

Perusahaan manufaktur yang terdaftar di Bursa Efek Indonesia pada tahun 2011-2012. Teknik Pengailan sampel metode purposive sampling.

\subsection{Data}

Jenis data yang digunakan dalam penelitian ini adalah data Sekunder. Data sekunder adalah data yang diperoleh secara tidak langsung melalui pihak lain atau perantara berupa laporan yang dipublikasikan kepada pihak luar.

Sumber data dalam penelitian ini berupa laporan tahunan perusahaan manufaktur yang terdaftar di Bursa Efek Indonesia pada periode tahun 2011-2012. Data tersebut diperoleh dari website Bursa Efek Indonesia, website perusahaan yang bersangkutan, internet, ataupun dengan perantara. 


\subsection{Model Penelitian Dan Pengujian Statistika}

\section{Model Penelitian}

\begin{tabular}{|l|l|}
\hline Manajemen Laba (X) & $\rightarrow$ Kinerja Keuangan (Y) \\
\hline $\begin{array}{l}\text { - Discretionary Accruals } \\
\text { Sumber : Jones model }\end{array}$ & $\begin{array}{l}\text { - Return On Assets (ROA) } \\
- \text { Debt to Equity Ratio } \\
\text { Sumber: Sawir (2001) }\end{array}$ \\
\hline
\end{tabular}

\section{Pengujian Statistika}

\section{Uji Statistik Deskriptif}

Statistik deskriptif merupakan sebuah pengujian yang memberikan gambaran atau deskripsi suatu data yang dilihat dari nilai rata-rata (mean), standar deviasi, varian, maksimum, minimum, sum, range, kurtosis dan skewness (Ghozali, 2006).

\section{Uji Hipotesis}

\section{Analisis Regresi}

Penelitian ini akan menggunakan analisis regresi linier sederhana, yaitu regresi yang terdiri dari satu variabel independen dan satu variabel dependen. Variabel independen dalam penelitian ini adalah manajemen laba yang diproksikan dengan menggunakan discretionary accruals, sedangkan variabel dependennya adalah kinerja keuangan perusahaan yang diproksikan dengan menggunakan return on asset dan debt to equity ratio.

\section{Model Analisis Regresi Sederhana}

Persamaan regresi dari variabel yang diteliti adalah sebagai berikut:

$\mathrm{Y}=\mathrm{a}+\mathrm{b}_{1} \mathrm{X}_{1}$

Keterangan:

$\mathrm{a}=$ konstanta

$\mathrm{b}_{1}=$ koefisien regresi

$\mathrm{X}_{1}=$ manajemen laba

$\mathrm{Y}=$ kinerja keuangan

\section{Uji Parsial (Uji t)}

Menurut Ghozali (2006) uji t pada dasarnya menunjukkan seberapa jauh pengaruh satu variabel independen secara individual dalam menerangkan variabel dependen. Pengujian dilakukan dengan menggunakan significance level 0,05 $(\alpha=5 \%)$. Penerimaan atau penolakan hipotesis dilakukan dengan kriteria sebagai berikut: 
a. Jika t-hitung $\geq$ t-tabel $(\alpha=0,05)$, maka hipotesis ditolak (koefisien regresi tidak signifikan). Hal ini berarti bahwa secara parsial variable independen tersebut tidak mempunyai pengaruh signifikan terhadap variabel dependen.

b. Jika t-hitung $\leq \mathrm{t}$-tabel $(\alpha=0,05)$, maka hipotesis diterima (koefisien regresi signifikan). Hal ini berarti bahwa secara parsial variabel independen tersebut mempunyai pengaruh signifikan terhadap variabel dependen.

\section{Uji Koefisien Determinasi $\left(\mathbf{R}^{2}\right)$}

Koefisien Determinasi $\left(\mathrm{R}^{2}\right)$ digunakan untuk mengukur sejauh mana variabel independen menjelaskan variabel dependen dengan nilai determinasi antara nol dan satu. Semakin kecil nilainya, berarti kemampuan variabel independen dalam menjelaskan variabel dependen terbatas. Nilai yang mendekati satu berarti variabel-variabel independen memberikan hampir seluruh informasi yang diperlukan untuk memprediksi variabel-variabel dependen. Koefisien determinasi dihitung dengan:

Koefisien Determinasi $=r^{2} \times 100 \%$

Karena sudah diketahui bahwa $0 \leq \mathrm{r}^{2} \leq 1$, maka koefisien determinasi tidak pernah negatif dan paling besar sama dengan (1). Dalam penggunannya koefisien determinasi dinyatakan dalam bentuk persen $(\%)$.

\subsection{Definisi Operasional Variabel Penelitian}

Variabel independen adalah variabel yang berpengaruh secara bebas positif maupun negatif terhadap variabel dependen (Sanusi, 2013). Penelitian ini menggunakan variabel Manajemen laba sebagai variabel independen yang ditinjau dengan menggunakan discretionary accruals. Variabel dependen adalah variabel yang dipengaruhi oleh variable independen (Sanusi, 2013). Variabel dependen penelitian ini adalah Return On Asset dan Debt to Equity Ratio. 
4. Hasil Dan Pembahasan

\subsection{Data Penelitian}

\begin{tabular}{|r|l|r|r|r|r|r|r|}
\hline \multirow{2}{*}{ No } & \multirow{2}{*}{ Kode } & \multicolumn{2}{|c|}{ Manajemen Laba } & \multicolumn{2}{c|}{ ROA } & \multicolumn{2}{c|}{ DER } \\
\cline { 3 - 8 } & & $\mathbf{2 0 1 1}$ & $\mathbf{2 0 1 1}$ & $\mathbf{2 0 1 1}$ & $\mathbf{2 0 1 2}$ & $\mathbf{2 0 1 2}$ & \multicolumn{1}{c|}{$\mathbf{2 0 1 2}$} \\
\hline 1 & ADES & 0,13 & 0,13 & 8,18 & 21,43 & 0,60 & 0,47 \\
\hline 2 & ALMI & 0,16 & 0,16 & 1,81 & 0,74 & 2,47 & 2,20 \\
\hline 3 & AUTO & 0,11 & 0,11 & 15,88 & 12,12 & 0,47 & 0,62 \\
\hline 4 & BTON & 0,20 & 0,20 & 16,09 & 16,99 & 0,29 & 0,28 \\
\hline 5 & CPIN & 0,16 & 0,16 & 26,70 & 21,71 & 0,43 & 0,51 \\
\hline 6 & DLTA & 0,07 & 0,07 & 21,79 & 28,64 & 0,21 & 0,25 \\
\hline 7 & ETWA & 0,24 & 0,24 & 11,75 & 3,09 & 0,65 & 1,20 \\
\hline 8 & GGRM & 0,13 & 0,13 & 12,68 & 9,80 & 0,59 & 0,56 \\
\hline 9 & HMSP & 0,18 & 0,18 & 41,55 & 37,36 & 0,90 & 0,97 \\
\hline 10 & INDS & 0,15 & 0,15 & 10,57 & 8,05 & 0,80 & 0,46 \\
\hline 11 & JECC & 0,00 & 0,00 & 4,59 & 4,52 & 3,92 & 3,96 \\
\hline 12 & MERK & 0,19 & 0,19 & 39,56 & 18,93 & 0,18 & 0,37 \\
\hline 13 & PSDN & 0,03 & 0,03 & 5,66 & 3,75 & 1,04 & 0,67 \\
\hline 14 & ULTJ & 0,14 & 0,14 & 4,65 & 14,60 & 0,65 & 0,44 \\
\hline 15 & VOKAS & 0,06 & 0,06 & 7,03 & 8,66 & 2,17 & 1,82 \\
\hline
\end{tabular}

\subsection{Deskripsi Statistik Variabel Penelitian}

Descriptive Statistics

\begin{tabular}{|l|r|r|r|r|r|}
\hline & \multicolumn{1}{|c|}{$\mathrm{N}$} & \multicolumn{1}{|c|}{ Minimum } & Maximum & \multicolumn{1}{c|}{ Mean } & Std. Deviation \\
\hline X MANAJEMEN & 30 &, 0030 &, 2693 &, 092350 &, 0749481 \\
LABA & & & & & \\
Y1 ROA & 30 &, 7400 & 41,5500 & 14,629333 & 11,1550369 \\
Valid N (listwise) & 30 & & & & \\
\hline
\end{tabular}

Descriptive Statistics

\begin{tabular}{|l|r|r|r|r|r|}
\hline & \multicolumn{1}{|c|}{ N } & Minimum & Maximum & \multicolumn{1}{c|}{ Mean } & Std. Deviation \\
\hline X MANAJEMEN & 30 &, 0030 &, 2693 &, 092350 &, 0749481 \\
LABA & & & & & \\
Y2 DER & 30 &, 1800 & 3,9600 & 1,005000 & 1,0009022 \\
Valid N (listwise) & 30 & & & & \\
\hline
\end{tabular}

Berdasarkan hasil pengolahan data pada tabel 4.2 dan tabel 4.3 diketahui bahwa:

1. Nilai rata-rata variabel Manajemen Laba (Earnings Management) adalah 0,092350.

Nilai maksimum sebesar 0,2693; sedangkan nilai minimumnya sebesar 0,0030.

2. Return on Asset menunjukkan nilai rata-rata sebesar 14,629333. Nilai maksimum sebesar 41,5500; sedangkan nilai minimumnya sebesar 0,7400

3. Debt To Equity Ratio menunjukkan nilai rata-rata sebesar 1,005000. Nilai maksimum sebesar 3,9600, sedangkan nilai minimumnya sebesar 0,1800 . 
Analisis Regresi Linier Sederhana

Pengaruh Manajemen Laba terhadap Return On Asset

Berdasarkan hasil perhitungan dengan menggunakan program SPSS 18, diperoleh hasil

Tabel 1

Coefficients $^{\mathrm{a}}$

\begin{tabular}{|c|c|c|c|c|c|c|}
\hline \multirow{2}{*}{\multicolumn{2}{|c|}{ Model }} & \multicolumn{2}{|c|}{$\begin{array}{l}\text { Unstandardized } \\
\text { Coefficients }\end{array}$} & $\begin{array}{l}\text { Standardized } \\
\text { Coefficients }\end{array}$ & \multirow[b]{2}{*}{ l } & \multirow[b]{2}{*}{ Sig. } \\
\hline & & B & Std. Error & Beta & & \\
\hline & (Constant) & 7,434 & 2,832 & & 2,626 &, 014 \\
\hline & $\begin{array}{l}\text { X MANAJEMEN } \\
\text { LABA }\end{array}$ & 77,909 & 23,966 &, 523 & 3,251 & ,003 \\
\hline
\end{tabular}

a. Dependent Variable: Y1 ROA

perhitungan seperti tabel berikut:

$\mathrm{Y}_{1}=7,434+77,909 \mathrm{X}$

Coefficients $^{\mathrm{a}}$

\begin{tabular}{|c|c|c|c|c|c|c|}
\hline \multirow{2}{*}{\multicolumn{2}{|c|}{ Model }} & \multicolumn{2}{|c|}{$\begin{array}{l}\text { Unstandardized } \\
\text { Coefficients }\end{array}$} & $\begin{array}{l}\text { Standardize } \\
\text { Coefficient }\end{array}$ & \multirow[b]{2}{*}{ l } & \multirow[b]{2}{*}{ Sig. } \\
\hline & & $\mathrm{B}$ & Std. Error & Beta & & \\
\hline & (Constant) & 1,390 & 283 & & 4,909 &, 000 \\
\hline & X MANAJEMEN LABA & $-4,174$ & 2,397 &,- 31 & $-1,741$ & ,093 \\
\hline
\end{tabular}

a. Dependent Variable: Y2 DER

$$
\mathrm{Y}_{2}=1,390-4,174 \mathrm{X}
$$

\subsection{Uji Parsial (Uji t)}

Uji t dilakukan untuk menguji tingkat signifikasi pengaruh variabel independen berupa manajemen laba yang diukur dengan discretionary accruals terhadap variabel dependen berupa kinerja keuangan yang diukur dengan return on asset dan debt to equity secara parsial. Uji ini dilakukan dengan membandingkan nilai p-value dengan tingkat signifikasi sebesar $\alpha=0,05$ atau 5\%.

\section{Pengaruh Manajemen Laba terhadap Return On Asset}

Berdasarkan tabel diketahui bahwa nilai $\mathrm{p}$-value atau $\alpha=0,05$ lebih besar dari nilai $\mathrm{t}$ tabel atau signifikasi pada 0,003, maka manajemen laba berpengaruh signifikan terhadap return on asset pada level 5\%. 


\section{Pengaruh Manajemen Laba terhadap Debt to Equity Ratio}

Berdasarkan tabel diketahui bahwa nilai $p$-value atau $\alpha=0,05$ lebih kecil daripada $t$ tabel atau signifikasi pada 0,093, maka manajemen laba berpengaruh tidak signifikan negatif terhadap debt to equity ratio pada level $5 \%$, tetapi sigifikan pada level $10 \%$.

\section{Uji Koefisien Determinasi $\left(\mathbf{R}^{2}\right)$}

\begin{tabular}{|l|l|r|r|c|}
\multicolumn{1}{c|}{ Model Summary $^{\mathbf{b}}$} \\
\cline { 2 - 6 } & Model & \multicolumn{1}{c|}{ R Square } & $\begin{array}{c}\text { Adjusted R } \\
\text { Square }\end{array}$ & $\begin{array}{c}\text { Std. Error of the } \\
\text { Estimate }\end{array}$ \\
\hline 1 &, $523^{\mathrm{a}}$ &, 274 &, 248 & 9,6729203 \\
\hline
\end{tabular}

\section{a. Predictors: (Constant), X MANAJEMEN LABA \\ b. Dependent Variable: Y1 ROA}

Berdasarkan tabel diatas bahwa dari hasil perhitungan diperoleh nilai koefisien determinasi sebesar 0,274 atau 27,4\% yang berarti bahwa variabel independen manajemen laba dapat menjelaskan $27,4 \%$ terhadap return on asset.

\begin{tabular}{|l|r|r|r|c|}
\multicolumn{1}{c|}{ Model Summary $^{\mathbf{b}}$} \\
\cline { 2 - 6 } & $\mathrm{R}$ & \multicolumn{1}{c|}{ R Square } & $\begin{array}{c}\text { Adjusted R } \\
\text { Square }\end{array}$ & $\begin{array}{c}\text { Std. Error of the } \\
\text { Estimate }\end{array}$ \\
\hline 1 &, $313^{\mathrm{a}}$ &, 098 &, 098 &, 9675855 \\
\hline
\end{tabular}
a. Predictors: (Constant), (X) MANAJEMEN LABA
b. Dependent Variable: Y2 DER

Berdasarkan tabel 4.6 diatas bahwa dari hasil perhitungan diperoleh nilai koefisien determinasi sebesar 0,098 atau 9,8\% yang berarti bahwa variabel independen manajemen laba menjelaskan $9,8 \%$ terhadap debt to equity ratio.

\subsection{Kesimpulan}

Kesimpulan - kesimpulan dalam penelitian ini adalah:

1. Manajemen laba berpengaruh signifikan positif karena berdasarkan tabel diketahui bahwa nilai $p$-value atau $\alpha=0,05$ lebih besar dari nilai $t$ tabel atau signifikasi pada 0,003, sehingga manajemen laba berpengaruh signifikan terhadap return on asset.

2. Berdasarkan tabel diketahui bahwa nilai $p$-value atau $\alpha=0,05$ lebih kecil daripada $t$ tabel atau signifikasi pada 0,093, maka manajemen laba berpengaruh tidak signifikan negatif terhadap debt to equity ratio. 


\subsection{Saran}

1. Berdasarkan beberapa keterbatasan penelitian yang telah diungkapkan, maka diberikan beberapa saran dari penelitian ini untuk penelitian selanjutnya antara lain:

2. Penelitian selanjutnya disarankan agar dapat menggunakan variabel yang lebih luas untuk memberikan hasil analisis yang lebih beragam.

3. Menambah periode pengamatan sehingga lebih mengetahui dampak jangka panjang aktivitas manajemen laba.

4. Perusahaan sebaiknya melakukan manajemen laba tanpa melanggar batasan yang telah ditentukan untuk menghindari dampak negatif dari tindakan penyalahgunaan praktik manajemen laba

\section{Daftar Pustaka}

Angkoso, Nandi. 2006. Akuntansi Lanjutan. Penerbit. FE Yogyakarta.

Anthony dan Govindarajan. 2005. Management Control System, Jakarta: Salemba Empat.

Assih, Prihat dan Gudono. 2000. Hubungan Tindakan Perataan Laba Dengan Reaksi Pasar Atas Pengumuman Informasi Laba Perusahaan Yang Terdaftar di Bursa Efek Jakarta" Jurnal Riset Akuntansi Indonesia, Vol. 3, No. 1, hal 35-53.

Chariri, Gozali. 2003. Teori Akuntansi, Badan Penerbit Universitas Diponegoro Semarang.

Dahlan, Muhammad. 2009. Analisis Hubungan Antara Kualitas Audit Dengan Diskresioner Akrual dan Kebebasan Auditor. Universitas Padjajaran: Departemen Akuntansi.

Djarwanto. 2004. Pokok-pokok Analisa Laporan Keuangan, Edisi Kedua, Cetakan Pertama, Yogyakarta: BPFE.

Ermayanti, Dwi. 2009. Kinerja Keuangan Perusahaan (www.wordpress.com, diakses Juli 2014).

Ghozali, Imam. 2005. Aplikasi Analisis Multivariate dengan Program SPSS. Semarang, Edisi 3 Badan Penerbit UNPAD.

Harahap, Sofyan Syafiri. 2007. Teori Akuntansi. Edisi Revisi. Jakarta: PT Raja Grafindo Persada.

Hendriksen, Breda. 2000. Theory Accounting. Inter Askara, Batam.

Jensen, M. C and Meckling, W.H. 1976. Theory of the Firm : Managerial Behavior, Agency Costs and Ownership Structure . Journal of Financial Economics, Oktober, 1976, V. 3, No. 4, pp. 305-360. Avalaible from: http://papers.ssrn.com

Jones, Charles. 1991. Pengantar Kebijakan Publik (terjemahan Ricky Istamto). Jakarta, Rayawali. 
Kurnianto, Heru. 2009. Penilaian Kinerja Karyawan Berdasarkan Definisi, Tujuan dan Manfaat (http://jurnal-sdm.blogspot.com/2009/04/penilaian- kinerja-karyawandefinisi.html).

Meutia, I. (2004). Pengaruh Independensi Auditor Terhadap Manajemen Laba untuk KAP Big 5 dan Non Big 5. Jurnal Riset Akuntansi Indonesia, 7 (3), 333-350.

Rahmawati, Y. Suparno, dan N. Qomariyah. 2006. Pengaruh Asimetri Informasi Terhadap Praktik Manajemen Laba Pada Perusahaan Perbankan Publik Yang Terdaftar Di Bursa Efek Jakarta. Makalah SNA IX Padang, 1-28.

Restuti, Maria Immaculata. 2006. Pengaruh Pertumbuhan Perusahaan Terhadap Peringkat Obligasi Dan Yield Obligasi. Jurnal Akuntansi dan Keuangan, Volume 1 No 3, 2007.

Riyanto. 2001. Dasar-Dasar Pembelajaran Perusahaan. Yogyakarta: BPFE.

Riyanto, Basuki. 2001. Manajemen Keuangan. Penerbit Erlangga.

Sawir, Agnes. 2001. Analisis Kinerja Keuangan dan Perencanaan Keuangan Perusahaan. Jakarta: PT Gramedia Pustaka Utama.

Scott, William R., 2000, Financial Accounting Theory, Canada: Prentice Hall, 2nd edition.

Simamora, Henry, 2000. Akuntansi Basis Pengambilan Keputusan Bisnis. Jakarta: 528.

Sri, Sulistyanto. 2008. Manajemen Laba: Teori Dan Model Empiris. Jakarta: Grasindo.

Tangkilisan, Hesel. 2003. Implementasi Kebijakan Publik. Yogyakarta: Lukman Offset.

Van, Horne. 2005. Accounting Economics. Penerbit PT. Gramedia Pustaka Umum Jakarta : 225.

Watts, R.L. 1986. Positive Accounting Theory. New Jersey: Prentince-Hall International Inc.

Wild, John, et al (terjemahan Bachtiar dan Harahap). 2004. Analisis Laporan Keuangan Edisi ke delapan. Jakarta: Salemba Empat.

Yusuf, H. 2001. Dasar-Dasar Akuntansi. Edisi Enam. Yogyakarta: STIE YPKN 